\section{EMBRYRIDDLE \\ Aeronautical University}

SCHOLARLY COMMONS

\section{International Journal of Aviation,} Aeronautics, and Aerospace

7-7-2017

\title{
Evolution of UAS policy in the wake of Taylor v. Huerta
}

Ryan J. Wallace

Polk State College, ryan.wallace@erau.edu

Jon M. Loffi

Oklahoma State University - Main Campus, jon.loffı@okstate.edu

Follow this and additional works at: https://commons.erau.edu/ijaaa

Part of the Air and Space Law Commons

\section{Scholarly Commons Citation}

Wallace, R. J., \& Loffi, J. M. (2017). Evolution of UAS policy in the wake of Taylor v. Huerta. International Journal of Aviation, Aeronautics, and Aerospace, 4(3). https://doi.org/10.15394/ijaaa.2017.1179

This Position Paper is brought to you for free and open access by the Journals at Scholarly Commons. It has been accepted for inclusion in International Journal of Aviation, Aeronautics, and Aerospace by an authorized administrator of Scholarly Commons. For more information, please contact commons@erau.edu. 
The Federal Aviation Administration (FAA) was left reeling after a federal appeals court in Washington ruled on May 22, 2017, that the agency exceeded their statutory authority in enacting mandatory drone registration for hobbyist flyers. As of May 23, 2017, the FAA's database included 836,577 registered drone operators, of which 764,830 were hobbyists (Larls, 2017). The recent decision left some UAS stakeholders wondering if the FAA is up to the challenge of leading the aviation industry into the drone age.

In oral arguments, petitioner John Taylor argued that the FAA's registration mandate violated Congressional intent to prevent additional rulemaking from being imposed on hobbyist or model aircraft operators. Codified in the FAA Modernization and Reform Act of 2012, Sec. 336(a), the legislation cites,

Notwithstanding any other provision of law relating to the incorporation of unmanned aircraft systems into the Federal Aviation Administration plans and policies, including this subtitle, the Administrator of the Federal Aviation Administration may not promulgate any rule or regulation regarding a model aircraft, or an aircraft being developed as a model aircraft if [the operation meets certain criteria, as articulated in $\operatorname{Sec} 336(a) 1-5]$.

FAA counsel Abby Wright responded, stating that the primary objectives of the registration system were to (1) ensure model aircraft could be identified for enforcement purposes; and, (2) to provide education for model aircraft users to operate safely.

The FAA counsel unsuccessfully argued that to adequately carry out enforcement actions against model aircraft operators who create a threat to the National Airspace System, the FAA needed the registration system as a means for operator identification.

While a logical premise for drone registration, Taylor explained that according to a FAA FOIA response, the agency's database had never been used to provide drone operator information for enforcement purposes (FAA, 2016a). Not that there was not enough cause to do so...From the UAS database's inception on December 21, 2015, to August 18, 2016 - the date the FAA responded to Taylor's FOIA request--1,177 UAS sightings were reported to the FAA (FAA, 2017). The agency made a clear statement condemning such activity (FAA, 2017):

The agency wants to send out a clear message that operating drones around airplanes, helicopters, and airports is dangerous and illegal. 
Unauthorized operators may be subject to stiff fines and criminal charges, including possible jail time...The agency also is working closely with the law enforcement community to identify and investigate unauthorized aircraft operations (p. 1).

This begs the question — what is the FAA doing with this database?

While the judges acknowledged registration was a good policy argument for preserving safety, the mandate still violated the statutory prohibition against FMRA Sec. 336(a), "promulgating any rule or regulation regarding a model aircraft." (Taylor v. Huerta, USCA No. 15-1495, 2015; FAA Modernization \& Reform Act of 2012).

In clarifying the FAA's position, counsel Wright further elucidated that the registration rule did not constitute new rulemaking, but rather drew upon the authority of existing registration requirements codified under 14 CFR Part 47. Wright further alluded that since 14 CFR Part 47 predated the FAA Modernization Act of 2012, it was not affected by the Sec. 336(a) prohibitions. When pressed about the applicability of the statutory limitations imposed by FMRA Sec. 336(a), Wright explained that the agency could not, for example, change the defining characteristics of a model aircraft. Senior Circuit Judge Edwards was quick to chide Wright's interpretation (Taylor v. Huerta, USCA No. 15-1495, 2015):

...where are you getting these words from? You're just making stuff up. That's not what the statute says...'Not withstanding any [verbal emphasis added] other provision of law...Y You know, I like my colleague to my right who says it's a very perplexing statute, but you know, it is what it is. And judges get themselves in trouble when you start fooling around. There are some judges that I can point to nationally who would say, 'well, this isn't what Congress said.' This $i$ [verbal emphasis added] what Congress said and you have five as difficult as you have-you have a frame-if the model is within these five ${ }^{1}$ [provisions of FMRA Sec 336(a)], you're done. That's that. That's what Congress said...

Summarizing the FAA's arguments, Judge Edwards continued (Taylor v. Huerta, USCA No. 15-1495, 2015):

${ }^{1}$ See Appendix for Act text. 
Your argument is very strange to read. 'We had the authority before-we didn't exercise it, so there's no existing regulation-we never regulated. Now the statute says 'don't regulate.' You had none- don't do any unless you meet the five criteria ${ }^{1}$. And you're saying, 'well, all that means is we can quickly do it now, but going forward we can't.' That just doesn't work. I wouldn't write anything like that; I'd be laughed out of the business.

In writing the court's opinion, Judge Kavanaugh articulates that the FAA exceeded its statutory authority, writing (Taylor v. Huerta, USCA No. 15-1495, 2015):

Section 336(a) of that Act [FMRA] states that the FAA 'may not promulgate any rule or regulation regarding model aircraft'...The FAA's 2015 Registration Rule, which applies to model aircraft directly violates that clear statutory prohibition...In short, the 2012 FAA Modernization and Reform Act provides that the FAA 'may not promulgate any rule or regulation regarding a model aircraft,' yet the FAA's 2015 Registration Rule is a 'rule or regulation regarding a model aircraft.' Statutory interpretation does not get much simpler. The registration rule is unlawful as it applied to model aircraft... The FAA's arguments to the contrary are unpersuasive.

\section{Reactions}

The Taylor ruling generated strong reactions from several unmanned aircraft stakeholders.

The Academy of Model Aeronautics (AMA) was quick to praise the Taylor ruling (AMA, 2017). AMA president Rich Hanson stated,

The AMA is encouraged to see the Court affirm the strength of the Special Rule for Model Aircraft, otherwise known as Section 336, under which our members operate. For decades, AMA members have registered their aircraft with AMA and have followed our community-based safety programming. It is our belief that a community-based program works better than a federally mandated program to manage the recreational community (p. 1).

The Small UAV Coalition (2017) expressed concern over the ruling, stating: 
The viability and growth of the UAS industry is contingent on the safe and responsible integration of UAS technology. This is only possible if all operators - commercial and recreational alike understand their responsibilities and remain informed of the evolving standards around UAS technology. Today's ruling generates uncertainty by eliminating a tool developed to maintain accountability and enable streamlined communication between the FAA and recreational operators (p. 1).

The Small UAV Coalition called the registration database a necessary "first step to identifying UAS operating in the national airspace" (Small UAV Coalition, 2017, p. 1). The Small UAV Coalition sees the Taylor decision as stripping the FAA of its necessary authority to preserve safety (2017).

In a prepared statement, President Brian Wynne from the Unmanned Aerial Vehicle Systems International (AUVSI) criticized the ruling, stating (AUVSI, 2017):

AUVSI is disappointed with the decision today by the U.S. Court of Appeals to reject the FAA's rule for registering recreational unmanned aircraft systems (UAS). A UAS registration system is important to promote accountability and responsibility by users of the national airspace, and helps create a culture of safety that deters careless and reckless behavior. We plan to work with Congress on a legislative solution that will ensure continued accountability across the entire aviation community, both manned and unmanned (p. 1).

DJI Vice President of Policy and Legal Affairs Brendan Schulman also criticized the ruling, stating, "Drone registration is a good policy because it promotes accountability and provides an opportunity for the FAA to educate pilots to the guidelines for safe operations" (Crowe, 2017, p. 1). Lisa Ellman, an attorney, specializing in drone law, echoed similar sentiments (Crowe, 2017):

The goal of the registration rule was to assist law enforcement and others to enforce the law against unauthorized drone flights and to educate hobbyists that a drone is not just a toy and operators need to follow the rules (p. 1). 


\section{Outcomes}

What are the likely outcomes, now that the model aircraft rule is now vacated?

\section{Model aircraft operators celebrate}

The Taylor ruling was something of a surprising upset for the FAA, which had traditionally been accustomed to receiving favorable court deference in aviation matters. Perhaps the chief issue with the registration database was the lack of buy-in from drone operators. Based on testimony in the Taylor case, model aircraft operators viewed the registration mandate as an unnecessary imposition and tax on their hobby. For responsible model aircraft operators, the Taylor decision lifts the inconvenient registration burden enacted by the agency in late 2015. For all practical purposes, however, responsible model aircraft operators are back to business as usual.

While some organizations are quick to point out the FAA's diminished authority over these hobbyists, this strong group of aviation enthusiasts-particularly those members of the AMA--do not present a serious safety threat to the national airspace system. The nearly 195,000 members of the AMA have demonstrated an active commitment to safe operations by joining an organization that aggressively promotes the importance of training, safety, and responsible recreational model aircraft operations.

\section{Uninformed drone operators continue, unabated}

It is important to distinguish this group from the responsible model aircraft operators annotated above. Categorically, these individuals represent drone operators that purchase and operate drones in ignorance or without regard for FAA rules, recommended safety practices, or other responsible encumbrances. For these operators, the Taylor ruling has no tangible impact, as they were unlikely to have complied with the regulation in the first place. It is this group of emboldened, unregulated flyers that represents the single greatest threat to the safety of the National Airspace System.

\section{Erosion of FAA gravitas}

With the FAA's flagship hobbyist drone registration provision deemed unlawful, agency gravitas in leading drone integration is rapidly eroding. In a prepared statement, the agency responded to the court's decision (FAA, 2016b): 
We are carefully reviewing the U.S. Court of Appeals decision as it relates to drone registrations. The FAA put registration and operational regulations in place to ensure that drones are operated in a way that is safe and does not pose security and privacy threats. We are in the process of considering our options and response to the decision (p. 1).

This statement is reflective of the laissez-faire, "wait and see" approach the agency has taken since the beginning of UAS integration. Unfortunately, this blow comes at a difficult time for the agency. The battered administration has long been the target of intense criticism from commercial UAS operators frustrated with the slow release of permanent UAS regulations. Before the publication of 14 CFR 107, some commercial UAS operators simply ignored FAA regulations entirely. With only a few token enforcement cases against unsafe UAS operations, the FAA seemed content to accept the status quo.

If drone operators were ambivalent about the FAA's de facto leadership about drone operations, they must certainly be questioning who is now setting the vector for unmanned aircraft policy. The recent shellacking meted out by the U.S. Court of Appeals leaves the administration grasping for credibility among a drone industry that is steam rolling ahead, dragging along the FAA by its ears.

\section{Increased state \& local regulation}

In the absence of aggressive FAA enforcement, a plethora of state and local lawmakers are addressing constituent safety and privacy concerns by enacting new local ordinances aimed at curtailing UAS operations within their jurisdictions. According to a Syracuse University Institute for National Security \& Counterterrorism report (n.d.), legislation has been proposed or enacted in all 50 states and several municipalities. A separate report by Bard College's Center for the Study of the Drone cited that at least 133 localities in 31 states had enacted drone legislation (Michel, 2017). According to the report, most municipalities enacted restrictions on the flight over public and private property, limitations of law enforcement use of drones, and flight over critical infrastructure (Michel, 2017). The FAA recognizes too late that local regulation is quickly supplanting the agency's authority, creating a complex patchwork quilt of varied drone rules across the country. The recent loss of the Taylor case further erodes the public's confidence in the agency's ability to effectively regulate unmanned aircraft. 


\section{Congressional response}

Congress seems to have detected the agency's dwindling influence. Mere days after the Taylor ruling was announced, Senators Dianne Feinstein (D-CA), Richard Blumenthal (D-CT), Mike Lee (R-UT), and Tom Cotton (R-AR), cosponsored sweeping legislation under the Drone Federalism Act of 2017. The proposed bill curtails the scope of the FAA's regulatory authority to "the extent necessary to ensure the safety and efficiency of the national airspace system for interstate commerce..." (Drone Federalism Act, 2017, p. 2). The proposed legislation directs the FAA administrator to defer public safety, privacy, property, land use, nuisance, and pollution issues to state and local governments (Drone Federalism Act, 2017). This action serves as a strong rebuke of the FAA's leadership in driving integration efforts.

\section{Enforcement issues persist}

In losing the Taylor case, the agency bemoaned the loss of its key enforcement tool. In theory, drone registration makes sense - provided that all drone operators properly register, by the mandate. Unfortunately, such a policy is not pragmatic as some individuals - either through ignorance or active disobedience--do not follow the rules.

This is analogous to gun registration or gun control. The act of requiring persons to register their firearms is touted as a means to reduce violent crime. Like firearms, drone registration is unlikely to reduce the illicit use of these devices. The registration policy was reactionary in design and ill-suited to deal with the sheer quantity and types of violations of a small population of irresponsible drone operators. Meanwhile, serious UAS safety violations continue unabated.

\section{Conclusion}

As controversial as this ruling is, it is now in the camp of the FAA to decide an appropriate path forward. The agency can either appeal the decision, solicit congressional action to develop new legislative solutions, or accept the court's ruling and find new methods of investigating, identifying, and enforcing against unsafe UAS operations.

Meanwhile, the number of hobbyist and commercial UAS operations are continuing to grow exponentially across the nation. Now is not the time to retreat, but rather to exhibit industry leadership. Hopefully, the Federal Aviation 
International Journal of Aviation, Aeronautics, and Aerospace, Vol. 4 [2017], Iss. 3, Art. 5

Administration quickly picks itself up off the dirt and gets back to the daunting task of protecting the safety of the National Airspace System. 


\section{References}

Academy of Model Aeronautics. (2017). AMA statement of Federal Court of Appeals ruling on the FAA registration rule. Retrieved from http://www.modelaircraft.org/files/aboutama/AMAStatementonFederalCo urtofAppealsRulingontheFAARegistrationRule.pdf

Association for Unmanned Vehicle Systems International. (2017). AUVSI statement on U.S. Court of Appeals decision on UAS registration. Retrieved from http://www.auvsi.org/blogs/auvsiadvocacy/2017/05/19/auvsi-statement-on-us-court-of-appeals-decision-onuas-registration

Crowe, S. (2017) FAA's recreational drone registration struck down in court. Robotics Trends. Retrieved from http://www.roboticstrends.com/article/ faas_recreational_drone_registration_struck_down_in_court

Drone Federalism Act of 2017, [Bill Number Not Yet Designated], 115th Congr. (2017). Retrieved from https://lnkd.in/e2ZTskC

Federal Aviation Administration (2017). UAS sightings report [database]. Retrieved from https://www.faa.gov/uas/resources/uas_sightings_report/

Federal Aviation Administration. (2016a). Freedom of Information Act response to Mr. John Taylor [FOIA Request: 2016-005808].

Federal Aviation Administration. (2016b). Press release: FAA statement regarding U.S. Court of Appeals Decision. Retrieved from https://www.faa.gov/news/press_releases/news_story.cfm?newsId=21674

Larls, M. (2017). John Taylor fought the FAA over registering drones and won, but now what. Washington Post. Retrieved from https://www.washingtonpost.com/local/trafficandcommuting/john-taylorfought-the-faa-over-registering-drones-and-won-but-now-what/2017/05/ 29/56b83bf8-416a-11e7-adba-394ee67a7582_story.html?utm_term= $.6 \mathrm{e} 4 \mathrm{~b} 6090 \mathrm{ca} 17$

Small UAV Coalition. (2017). DC Appeals Court rules UAS registration unlawful [press release]. Retrieved from http://www.smalluavcoalition.org/wpcontent/uploads/2017/05/Small-UAV-Coalition-Press-Release-onRegistration-Ruling.pdf 
Syracuse University Institute for National Security \& Counterterrorism. (n.d.).

Domesticating the drone: Evaluating privacy policy in the use of unmanned aerial vehicles . Retrieved from http://uavs.insct.org/ 


\section{Appendix}

FAA MODERNIZATION AND REFORM ACT, P.L. 112-92 (EXCERPT) SEC. 336 SPECIAL RULE FOR MODEL AIRCRAFT

(a) IN GENERAL - Not withstanding any other provision of law relating to the incorporation of unmanned aircraft systems into Federal Aviation

Administration plans and policies, including this subtitle, the Administrator of the Federal Aviation Administration may not promulgate any rule or regulation regarding a model aircraft, or an aircraft being developed as a model aircraft, if:

1) The aircraft is flown strictly for hobby or recreational use;

The aircraft is operated in accordance with a community based set of safety guidelines and within the programming of a nationwide community-based organization;

2) The aircraft is limited to not more than 55 pounds unless otherwise certified through a design, construction, inspection, flight test, and operational safety program administered by a community-based organization;

3) The aircraft is operated in a manner that does not interfere with and gives way to any manned aircraft; and

4) When flown within 5 miles of an airport, the operator of the aircraft provides the airport operator and the airport air traffic control tower (when an air traffic facility is located at the airport) with prior notice of the operation (model aircraft operators flying from a permanent location within 5 miles of an airport should establish a mutually-agreed upon operating procedure with the airport operator and the airport air traffic control tower (when an air traffic facility is located at the airport)).

(a) STATUTORY CONSTRUCTION-Nothing in this section shall be construed to limit the authority of the Administrator to pursue enforcement action against persons operating model aircraft who endanger the safety of the national airspace system.

(b) MODEL AIRCRAFT DEFINED—-In this section, the term "model aircraft" means an unmanned aircraft that is-

1) Capable of sustained flight in the atmosphere;

2) Flown within visual line of sight of the person operating the aircraft; and Flown for hobby or recreational purposes 